\title{
INTERAKSI BIOKIMIA PADA REGULASI CAIRAN TUBUH Sebuah Tinjauan Pustaka
}

\author{
Reynardi Sutanto ${ }^{1}$, Ghina Rania ${ }^{1}$ \\ ${ }^{1}$ Program Studi Pendidikan Dokter, Fakultas Kedokteran Universitas Indonesia \\ Jakarta
}

\begin{abstract}
ABSTRAK
Interaksi biokimia di dalam tubuh merupakan salah satu dari topik fisiologi yang paling mendasar. Adapun salah satu interaksi biokimia yang paling penting untuk diketahui adalah pengetahuan tentang regulasi cairan tubuh. Sekitar $50-70 \%$ tubuh seorang manusia terdiri atas cairan. Karena proporsinya yang besar, perubahan pada kondisi cairan tubuh dapat memberikan efek besar bagi kelangsungan hidup manusia. Oleh sebab itu, tubuh akan berusaha untuk melakukan serangkaian regulasi cairan agar homeostasis dapat terjaga. Tinjauan pustaka ini ditulis untuk mengetahui interaksi biokimia dalam regulasi tersebut. Setelah menelusuri 9 (sembilan) literatur ilmiah berbeda, peneliti menyimpulkan bahwa regulasi cairan tubuh manusia terdiri atas serangkaian tindakan untuk menjaga $\mathrm{pH}$ tubuh. Untuk melakukannya, tubuh menggunakan sistem dapar yang terdiri atas dapar kimia dan fisiologis yang didasarkan atas berbagai konsep biokimia, seperti osmolaritas, asam dan basa, larutan dapar, serta kesetimbangan kimia. Dengan demikian, dapat disimpulkan bahwa konsep-konsep dasar biokimia memainkan peranan penting dalam praktik klinik ilmu kedokteran.
\end{abstract}

Kata kunci: biokimia, cairan tubuh, fisiologi

\begin{abstract}
Biochemical interaction inside the body is one of the most basic topics of physiology. Of all the biochemical interactions, one of the most prominent is the knowledge about biochemical interaction on bodily fluids regulation. Around $50-70 \%$ of the human body consists of fluids. Because of the large proportion occupied, change in bodily fluids condition could tremendously affect the well-being of a human being. Hence, the body will try to regulate bodily fluids so that homeostasis may be preserved. This literature review is conducted to shed light on biochemical interactions on that regulation. After researching 9(nine) different medical literatures, researchers conclude that human bodily fluids regulation consist of measures taken to control body $\mathrm{pH}$. In order to accomplish this, the body uses a buffer system consists of chemical and physiological parts which are based on many concepts of biochemistry, such as osmolarity, acid-base interaction, buffer solution, and chemical equilibrium. Thus, biochemical concepts play a major role in practical clinical practice of medicine.
\end{abstract}

Keywords: biochemistry, bodily fluids, physiology

\section{PENDAHULUAN}

Interaksi biokimia merupakan salah satu dari sekian banyak topik penting dalam ilmu fisiologi. Meski tampak sebagai dua cabang ilmu yang berbeda, biokimia dan fisiologi pada ilmu kedokteran memiliki keterkaitan yang sangat erat. IImu biokimia yang mempelajari interaksi zat serta proses kimia yang terjadi pada makhlukmakhluk hidup selama perkembangan dan kehidupannya merupakan basis dari kajian fungsi kehidupan makhluk hidup yang dipelajari pada fisiologi. ${ }^{1,2}$ Konsepkonsep biokimia, seperti osmolaritas, asam dan basa, larutan dapar, serta 
kesetimbangan kimia merupakan basis dari berbagai penjelasan fisiologis manusia. Adapun dari sekian banyak interaksi biokimia yang terdapat dalam tubuh, interaksi yang memainkan peranan penting merupakan interaksi biokimia pada regulasi cairan tubuh.

Sekitar $50-70 \%$ tubuh seorang manusia terdiri atas cairan. Cairan ini terdistribusi ke dalam dua kompartemen tubuh, yaitu cairan intraseluler dan cairan ekstraseluler. Karena proporsinya yang besar, perubahan pada kondisi cairan tubuh dapat memberikan efek besar bagi kelangsungan hidup manusia. ${ }^{3}$ Oleh sebab itu, tubuh akan selalu berusaha meregulasi kondisi cairannya sehingga homeostasis tetap terus terjaga.

Biokimia merupakan cabang ilmu yang mempelajari keadaan kimiawi makhluk hidup beserta proses-proses vitalnya. ${ }^{4}$ Biokimia memainkan peranan penting dalam pemahaman berbagai proses yang terjadi pada zat-zat penyusun cairan tubuh. Karya tulis ini akan membahas beragam interaksi biokimia yang turut meregulasi cairan tubuh, seperti osmolaritas, asam dan basa, larutan dapar, serta kesetimbangan kimia.

\section{METODE}

Tulisan ini dibuat dengan mempertimbangkan penelusuran literatur (literature review) dari literatur ilmiah, referensi lain yang bisa ditelusuri, dan buku teks termutakhir dan terpercaya mengenai topik interaksi biokimia pada regulasi cairan tubuh.

\section{HASIL PENELITIAN}

Setelah melakukan penelusuran literatur, peneliti menemukan 3 (tiga) buku teks, 9 (sembilan) literatur penelitian, dan 3 (tiga) kuliah umum yang dapat digunakan untuk menyusun tinjauan pustaka ini. Tinjauan pustaka disusun secara sistematis dan holistis oleh 2 (dua) peneliti dengan mempertimbangkan hubungan air dan osmolaritas, dasar interaksi asam dan basa, larutan dapar, serta gangguan fisiologis yang diakibatkan oleh masalah interaksi biokimia pada tubuh manusia.

\section{PEMBAHASAN}

\subsection{Air Dan Osmolaritas}

Cairan tubuh terdistribusi ke dalam dua kompartemen, yaitu cairan intraseluler dengan proporsi $2 / 3$ cairan tubuh dan ekstraseluler dengan proporsi $1 / 3$. Cairan ekstraseluler sendiri dapat dibagi menjadi dua kompartemen, yaitu cairan plasma yang terletak pada pembuluh darah dan cairan interstisium yang mengisi ruang antarsel. ${ }^{3}$ Cairancairan ini terdiri atas air sebagai pelarut dan molekul-molekul kimia lainnya yang terlarut. Karena berperan sebagai pelarut, konsentrasi air sangat tinggi dalam cairan. Sebagai contoh, $91-92 \%$ cairan plasma merupakan air. ${ }^{5}$

Di antara setiap kompartemen cairan tubuh, terdapat membran seluler yang semipermeabel. Membran ini terdiri atas dua lapisan fosfolipid dengan kepala nonpolar yang hanya permeabel terhadap molekul-molekul nonpolar. ${ }^{3}$ Bagi molekul-molekul lain yang bersifat polar, seperti air, cara melewati membran ini adalah dengan menggunakan protein transporter yang terletak pada membran tersebut. ${ }^{6}$

Protein transporter untuk air dapat ditemukan dalam jumlah besar pada membran selular dan bersifat transport pasif. Oleh sebab itu, air dapat berpindah menuju berbagai kompartemen cairan tubuh dengan bebas. Akan tetapi, hal yang sama tidak berlaku pada molekul-molekul polar lainnya, seperti ion-ion $\mathrm{Na}^{+}, \mathrm{K}^{+}, \mathrm{HCO}_{3}{ }^{-}$, dan lain-lain. ${ }^{6} \quad$ Akibatnya, terjadi perbedaan konsentrasi zat terlarut antarkompartemen cairan tubuh. Sebagai respons natural terhadap hal tersebut, air akan berpindah dari daerah dengan konsentrasi rendah ke daerah dengan konsentrasi yang lebih tinggi. Proses ini disebut sebagai osmosis. . $^{3,7,8}$

Pada biokimia cairan tubuh, konsentrasi zat terlarut dihitung dengan nilai osmolaritas larutan. Osmolaritas adalah jumlah partikel osmotik aktif larutan yang dikalikan dengan konsentrasi larutan tersebut dan memiliki satuan mOsm/L. ${ }^{3,8}$ Secara 
matematis, osmolaritas dapat didefinisikan sebagai:

$$
\text { osmolaritas }=g . C
$$

$g=$ jumlah partikel osmotik aktif larutan (Osm/mol)

$C=$ konsentrasi larutan $(\mathrm{mmol} / \mathrm{L})$

Patut diingat bahwa konsentrasi larutan berbeda dengan osmolaritas karena konsentrasi larutan tidak memperhitungkan disosiasi molekul terlarut yang meningkatkan jumlah partikel osmotik aktif larutan. Pada beberapa keadaan, nilai konsentrasi zat terlarut tidak diekspresikan menggunakan osmolaritas, melainkan osmolalitas. Osmolalitas memiliki satuan $\mathrm{mOsm} / \mathrm{kg}$. Karena $1 \mathrm{~kg}$ air memiliki volume sekitar $1 \mathrm{~L}$, osmolaritas dan osmolalitas biasanya memiliki angka yang sama. 3,8

Perpindahan air yang terjadi pada osmosis dapat dicegah oleh sebuah tekanan yang disebut tekanan osmotik. Tekanan osmotik ( $\pi)$ dipengaruhi oleh nilai osmolaritas, jenis zat terlarut, dan suhu larutan. Tekanan ini dapat diukur dengan menggunakan persamaan van't Hoff, yaitu: ${ }^{3}$

$$
\pi=\text { osmolaritas } . \sigma . R . T
$$

$\sigma=$ Koefisien refleksi zat terlarut $(0$ bagi molekul yang sangat permeabel hingga

1 bagi molekul yang sangat tidak permeabel)

$R=$ Konstanta Gas (0.082 L.atm/mol.K) $T=$ Suhu absolut $(\mathrm{K})$

\subsection{Asam dan Basa \\ 4.2.1 Definisi}

Dalam definisi tradisionalnya menurut Arrhenius, asam merupakan molekul yang menghasilkan ion $\mathrm{H}^{+}$pada larutan berair, sementara basa merupakan molekul yang menghasilkan ion $\mathrm{OH}^{-}$pada larutan berair. Teori lain yang lebih modern dan universal dikemukakan oleh Brønsted dan Lowry. Menurut mereka, asam adalah molekul yang mendonorkan proton $\left(\mathrm{H}^{+}\right)$, sementara basa adalah molekul yang menerima proton. ${ }^{9-11}$

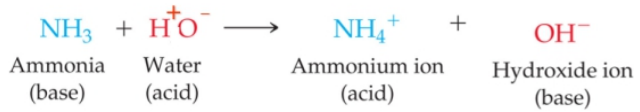

Gambar 1. Teori Asam-Basa BrønstedLowry $^{10}$

Gambar 1
persamaan kimia
ammonia dan air menurut teori Brønsted-Lowry. Melalui gambar tersebut, dapat terlihat bahwa ammonia merupakan basa sementara air berperan sebagai asam. Pada sisi sebelah kanan, sisa molekul ammonia membentuk ion ammonium sementara air membentuk ion hidroksida. Pada sisi ini, sisa molekul-molekul reaktan bertukar sifat satu sama lain karena ion ammonium, bila bereaksi dengan ion hidroksida, akan mendonorkan proton, sementara ion hidroksida menerima proton. Pasangan antara molekul sebelum reaksi dan setelah reaksi, dengan pertukaran sifat yang terjadi, disebut sebagai pasangan asam-basa konjugasi (Gambar 2). ${ }^{10}$

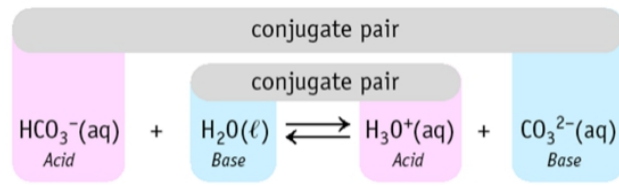

Gambar 2. Pasangan Asam-Basa Konjugasi ${ }^{10}$

Asam dan basa dapat
diklasifikasikan kemampuan ionisasinya menjadi asam atau basa kuat dan asam atau basa lemah. Asam atau basa yang kuat akan terdisosiasi secara sempurna dalam larutan. Contoh asam kuat adalah $\mathrm{HCl}$ sementara contoh basa kuat adalah $\mathrm{NaOH}$. Di sisi lain, asam atau basa yang lemah hanya akan terdisosiasi sebagian dalam larutan. Contoh asam lemah adalah asam laktat, sementara contoh basa lemah adalah ammonia.9,11

\subsubsection{Nilai $\mathrm{pH}$ dan $\mathrm{pOH}$}

Nilai pH merupakan sebuah formula logaritmik yang digunakan untuk mengekspresikan konsentrasi $\mathrm{H}^{+}$ (Gambar 3a). Sementara itu, nilai $\mathrm{pOH}$ digunakan untuk mengekspresikan konsentrasi $\mathrm{OH}^{-}$(Gambar 3b). Pada umumnya, nilai yang lebih sering dipakai adalah $\mathrm{pH}^{3,10}$ 


$$
\begin{aligned}
\text { a. } p H & =-\log \left[\mathrm{H}^{+}\right] \\
\text {b. } p O H & =-\log \left[\mathrm{OH}^{-}\right]
\end{aligned}
$$

Gambar 3. Formula pH (a) dan $\mathrm{pOH}$ (b)

Berdasarkan formulanya, peningkatan nilai $\mathrm{pH}$ berbanding terbalik dengan peningkatan konsentrasi $\mathrm{H}^{+}$ namun berbanding lurus dengan peningkatan konsentrasi $\mathrm{OH}^{-}$. Sebaliknya, peningkatan nilai $\mathrm{pOH}$ berbanding lurus dengan peningkatan konsentrasi $\mathrm{H}^{+}$namun dengan berbanding terbalik dengan konsentrasi $\mathrm{OH}^{-}$. Oleh sebab itu, dapat disimpulkan bahwa $\mathrm{pH}$ yang semakin kecil menandakan bahwa larutan tersebut lebih asam, begitu pula sebaliknya. Patut diingat pula bahwa $\mathrm{pH}$ yang disebut netral adalah $\mathrm{pH}=7$ karena pada kondisi tersebut baik nilai $\mathrm{pH}$ maupun $\mathrm{pOH}$ sama-sama bernilai 7.9,10

\subsubsection{Asam dan Basa pada Tubuh}

$\mathrm{pH}$ adalah salah satu parameter terpenting kehidupan. Perubahan pada $\mathrm{pH}$ berdampak pada banyak proses fisiologis tubuh, mulai dari tingkat seluler, jaringan, hingga sistemik. Pada tingkat seluler, $\mathrm{pH}$ memainkan peranan penting dalam menjaga keberlangsungan reaksi kimia, fungsi enzim serta protein lainnya, dan kerja organel. Pada tingkat jaringan dan sistem organ, $\mathrm{pH}$ tubuh turut serta mengatur aliran udara paru, penjagaan hidrasi dan transparansi kornea, serta penurunan, bila $\mathrm{pH}$ turun, maupun penaikan, bila $\mathrm{pH}$ naik, eksitabilitas saraf dan otot. ${ }^{9,12}$ Sementara secara sistemik, $\mathrm{pH}$ memodulasi interaksi elektrolit plasma serta aliran darah ke seluruh tubuh. ${ }^{10,12}$

Tubuh menggunakan berbagai mekanisme biokimia maupun fisiologis untuk mencapai nilai $\mathrm{pH}$ normal, yaitu di antara 7.35 sampai 7.45. Jika tubuh tidak mencoba mengatur kadar pH-nya, akumulasi asam sebesar 22.000 $\mathrm{mEq} /$ hari dapat terjadi dan $\mathrm{pH}$ akan cenderung turun ${ }^{6}$. Hal ini dapat terjadi karena metabolisme tubuh menghasilkan metabolit asam. Asamasam ini berasal dari metabolisme zatzat nutrisi makanan, seperti karbohidrat, protein, dan lemak (Gambar 4). 9,13

Adapun asam-asam metabolit tubuh meliputi asam karbonat, asam sulfat dan asam fosfat dari metabolisme protein, benda keton dari lemak, serta asam laktat dan $\mathrm{CO}_{2}$ dari glukosa. Asam-asam tersebut dikelompokkan ke dalam tiga kelompok besar, yaitu asam volatile yang mudah menguap, seperti asam karbonat, asam fixed yang tidak terpisahkan dengan larutan, seperti asam sulfat dan asam fosfat, serta asam organik yang merupakan hasil metabolisme anaerob, seperti asam laktat. ${ }^{9}$

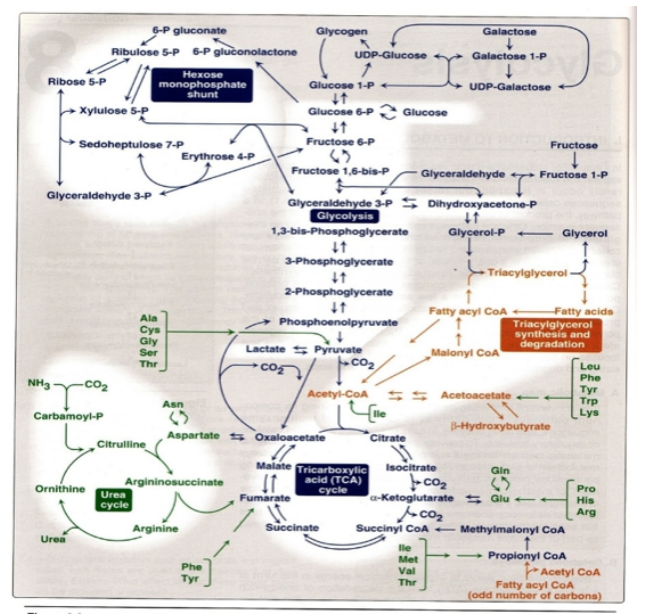

Gambar 4. Metabolisme makromolekul nutrisi menjadi asam ${ }^{9}$

\subsection{Larutan Dapar}

Dapar atau buffer mengandung asam lemah dan basa konjugasinya, atau sebaliknya, serta memiliki kemampuan menjaga $\mathrm{pH}$ suatu larutan meskipun terjadi penambahan ion $\mathrm{H}^{+}$ maupun ion $\mathrm{OH}^{-}$. Gambar 5 menerangkan mengenai apa yang terjadi pada larutan dapar asam asetat, yang ditulis sebagai HA, serta basa konjugasinya, asetat, yang ditulis sebagai $A^{-}$, ketika terjadi penambahan $\mathrm{OH}^{-6,14}$

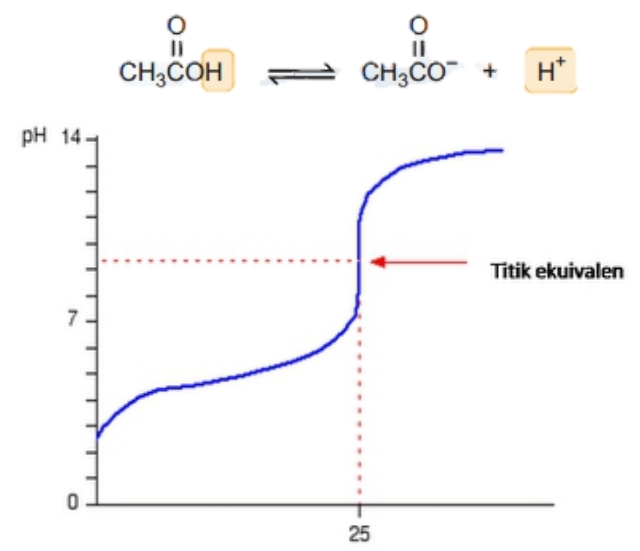


Gambar 5. Kurva titrasi dapar asam asetat $^{6,15}$

Pada penambahan 0.5 ekuivalen $\mathrm{OH}^{-}$, setengah $\mathrm{HA}$ telah terdisosiasi menjadi $A^{-}$, sehingga konsentrasi pasangan asam-basa konjugasi tersebut menjadi sama. Titik tengah ini diekspresikan oleh persamaan Henderson-Hasselbalch sebagai pKa. Di sebelah kiri maupun kanan pKa terlihat bahwa pengurangan atau penambahan $\mathrm{OH}^{-}$memiliki efek yang kecil terhadap perubahan $\mathrm{pH}$. Akan tetapi, akan ada suatu titik di mana salah satu pasangan asam-basa konjugasi ( $\mathrm{HA}$ dan $\mathrm{A}^{-}$) dapar telah tidak mampu lagi mengompensasi penambahan atau pengurangan $\mathrm{OH}^{-}$. Alhasil, perubahan $\mathrm{pH}$ menjadi lebih signifikan. 6,14

Persamaan

HendersonHasselbalch digunakan ntuk mengukur $\mathrm{pH}$ pada larutan dapar. Pada larutan dapar, $\mathrm{pH}$ dipengaruhi oleh nilai $\mathrm{pKa}$ asam tersebut dan konsentrasi asam dan basa konjugasinya ${ }^{10}$. Secara matematis, persamaan ini dituliskan sebagai:

$$
p H=p K a+\log \frac{[\text { basa konjugasi }]}{[\text { asam lemah }]}
$$

Di dalam tubuh, sistem dapar yang ditemukan meliputi sistem dapar bikarbonat-asam karbonat pada cairan ekstraseluler, sistem dapar fosfat pada semua tipe sel, dan sistem dapar protein milik sel dan plasma. ${ }^{6,9,16}$ Karena sistem dapar bikarbonat-asam karbonat merupakan dapar paling penting pada cairan ekstraseluler, kadarnya lebih muda diukur secara klinis dan berfungsi sebagai dapar terhadap perubahan asam nonkarbonat. ${ }^{13}$ Sistem dapar fosfat bekerja pada cairan intraseluler serta urin, sementara sistem dapar protein, yang meliputi dapar hemoglobin, asam amino, dan protein plasma, meregulasi $\mathrm{pH}$ pada kedua kompartemen cairan meski dengan pengaruh yang lebih kecil. ${ }^{10,16}$ Berikut merupakan formula reaksi kimia yang terjadi pada setiap sistem dapar:
1. Sistem Bikarbonat-Asam Karbonat

$\mathrm{CO}_{2}+\mathrm{H}_{2} \mathrm{O} \leftrightarrow \mathrm{H}_{2} \mathrm{CO}_{3} \leftrightarrow \mathrm{H}^{+}+\mathrm{HCO}_{3}^{-}$
Asam lemah: $\mathrm{H}_{2} \mathrm{CO}_{3}$ atau $\mathrm{CO}_{2}$ Basa konjugasi: $\mathrm{HCO}_{3}{ }^{-}$

\section{Sistem Fosfat}

$$
\begin{aligned}
& \mathrm{H}_{3} \mathrm{PO}_{4} \stackrel{\mathrm{K}_{1}}{\rightleftarrows} \mathrm{H}^{+}+\mathrm{H}_{2} \mathrm{PO}_{4}{ }^{\circ} \\
& \mathrm{H}_{2} \mathrm{PO}_{4}^{-} \stackrel{\mathrm{K}_{2}}{\rightleftarrows} \mathrm{H}^{+}+\mathrm{HPO}_{4}{ }^{2 \cdot} \\
& \mathrm{HPO}_{4}{ }^{2-} \stackrel{\mathrm{K}_{3}}{\rightleftarrows} \mathrm{H}^{+}+\mathrm{PO}_{4}^{3-}
\end{aligned}
$$

Asam lemah: $\mathrm{H}_{2} \mathrm{PO}_{4}{ }^{-}$atau $\mathrm{HPO}_{4}{ }^{2-}$ Basa konjugasi: $\mathrm{HPO}_{4}{ }^{2-}$ atau $\mathrm{PO}_{4}{ }^{3-}$

\section{Sistem Protein}

$$
\begin{aligned}
& \mathrm{R}-\mathrm{HC}-\mathrm{COOH} \leftrightarrows \mathrm{R}-\mathrm{HC}-\mathrm{COO}^{-} \leftrightarrows \mathrm{R}-\mathrm{HC}-\mathrm{COO} \\
& \mathrm{NH}_{3}{ }^{+} \quad \mathrm{NH}_{3}{ }^{+} \quad \mathrm{NH}_{2}
\end{aligned}
$$

Asam lemah: protein, gugus karboksil ($\mathrm{COOH})$

Basa konjugasi: protein, gugus amino ($\mathrm{NH}_{2}$ )

\subsection{Gangguan Kesetimbangan Asam- Basa}

Ketika $\mathrm{pH}$ tubuh lebih rendah atau lebih tinggi dari kadar normalnya, seperti saat mengalami hipoksia yang terinduksi oleh ketinggian atau hipoventilasi dan hiperventilasi, tubuh akan mengalami gangguan kesetimbangan asam-basa. Gangguan ini disebut sebagai asidosis bila $\mathrm{pH}$ tubuh rendah atau alkalosis bila $\mathrm{pH}$ tubuh meningkat. Untuk menjaga dan mengembalikan kondisi $\mathrm{pH}$, tubuh menggunakan tiga mekanisme kompensasi, yaitu melalui sistem dapar kimia, dapar paru, dan dapar ginjal. Dapar paru dan dapar ginjal merupakan kompensasi fisiologis, sementara dapar kimia menggunakan larutan dapar untuk menjaga $\mathrm{pH}^{9,13,17}$

Sistem dapar yang paling
berpengaruh terhadap kompensasi kimia adalah sistem dapar bikarbonat-asam karbonat. Ketika terjadi peningkatan ion hidrogen, kesetimbangan sistem ini akan bergeser ke arah pembentukan $\mathrm{CO}_{2}$ dan $\mathrm{H}_{2} \mathrm{O}$ akibat reaksi antara ion hidrogen dan ion bikarbonat. Begitu pula sebaliknya, alkalosis akibat kenaikan kadar $\mathrm{CO}_{2}$ akan menggeser kesetimbangan ke arah pembentukan ion hidrogen dan ion 
bikarbonat akibat reaksi $\mathrm{CO}_{2}$ dan $\mathrm{H}_{2} \mathrm{O}$. Perubahan ini dimediasi oleh enzim carbonic anhydrase. Dapar kimia lainnya, seperti protein hemoglobin bekerja dengan menjaga kadar $\mathrm{CO}_{2}$ dan $\mathrm{H}_{2} \mathrm{CO}_{3}$ sepanjang sistem kardiovaskuler sementara dapar fosfat bekerja pada ginjal. $^{6,13}$

\section{KESIMPULAN}

Bila proses homeostasis pada cairan tubuh mengalami gangguan, seperti pada perubahan $\mathrm{pH}$, gejala klinis dan patologis dapat muncul dan menyebabkan penyakit. Untuk menjaga $\mathrm{pH}$, tubuh menggunakan sistem dapar yang terdiri atas dapar kimia dan fisiologis. Maka, berbagai konsep biokimia, seperti osmolaritas, asam dan basa, larutan dapar, serta kesetimbangan kimia, memainkan peranan penting dalam praktik klinik ilmu kedokteran. Oleh sebab itu, dibutuhkan pemahaman mendasar akan aspek biokimia yang mendasari patofisiologi dari setiap penyakit cairan tubuh.

\section{UCAPAN TERIMA KASIH}

Peneliti mengucapkan terima kasih sebesar-besarnya terhadap fasilitas perpustakaan Universitas Indonesia yang memungkinkan akses terhadap penelusuran literature dalam tinjauan pustaka ini.

\section{DAFTAR PUSTAKA}

1. Stotz E. biochemistry [Internet]. Encyclopedia Britannica. 2020 [cited 2020 Nov 12]. Available from: https://www.britannica.com/science/bioc hemistry

2. Sheer B. physiology [Internet]. Encyclopedia Britannica. 2020 [cited 2020 Nov 12]. Available from: https://www.britannica.com/science/phys iology

3. Costanzo L. Physiology. 6th ed. Philadelphia: Elsevier; 2018. 1-14 p.

4. Albert D, Block A, Bruce B, Haines D, McCloskey L, Mitchell R, et al. Dorland's illustrated medical dictionary. 32nd ed.
Philadelphia: Elsevier Saunders; 2012. $216 \mathrm{p}$.

5. Długaszek M. Studies on relationships between essential and toxic elements in selected body fluids, cells and tissues. Chem Biol Interact. 2019 Jan 5;297:57-66.

6. Lieberman M, Marks A. Marks' basic medical biochemistry: a clinical approach. 4rd ed. Philadelphia: Lippincott Williams \& Wilkins; 2013. 43$51 \mathrm{p}$.

7. Hosseiniyan Khatibi SM, Zununi Vahed F, Sharifi S, Ardalan M, Mohajel Shoja M, Zununi Vahed S. Osmolytes resist against harsh osmolarity: Something old something new. Biochimie. 2019 Mar 1;158:156-64.

8. Rasouli M. Basic concepts and practical equations on osmolality: Biochemical approach. Clin Biochem. 2016 Aug;49(12):936-41.

9. Mudjihartini N. Biokimia Asam-Basa. Fakultas Kedokteran Universitas Indonesia; 2018 Feb; Depok.

10. Arsianti A. The chemistry of acids, bases, and buffers. Fakultas Kedokteran Universitas Indonesia; 2018 Jan; Depok.

11. Romero MF, Rossano AJ. Acid-Base Basics. Semin Nephrol. 2019;39(4):31627.

12.Occhipinti R, Boron WF. Mathematical modeling of acid-base physiology. Prog Biophys Mol Biol. 2015 Jan;117(1):43-58.

13. Yolanda S. Fluid, electrolyte, (acidbase) balance. Fakultas Kedokteran Universitas Indonesia; 2019 Jan 30; Depok.

14. Watanabe $\mathrm{K}$, Miyamoto $\mathrm{M}$, Imai $\mathrm{Y}$. An estimation of buffer values of human whole blood by titration experiment 
under the open condition for carbon dioxide gas. Jpn J Physiol. 2001 Dec;51(6):671-7.

15. Kimia I. Kurva Titrasi [Internet]. IImu Kimia | Artikel dan Materi Kimia. 2013 [cited 2020 Nov 12]. Available from: https://www.ilmukimia.org/2013/01/kurva -titrasi.html

16. Al-Gousous J, Sun KX, McNamara DP, Hens B, Salehi N, Langguth $P$, et al. Mass Transport Analysis of the Enhanced Buffer Capacity of the Bicarbonate-CO2 Buffer in a PhaseHeterogenous System: Physiological and Pharmaceutical Significance. Mol Pharm. 2018 05;15(11):5291-301.

17. Swenson ER. Hypoxia and Its AcidBase Consequences: From Mountains to Malignancy. Adv Exp Med Biol. 2016;903:301-23. 